\title{
Do Investment Agreements Matter?
}

\author{
Rashmi Banga \\ UNCTAD
}

\begin{abstract}
The study estimates the impact of bilateral investment agreements (BITs) on FDI inflows into fifteen Asian developing countries for the period 1980-81 to 19992000 and examines whether signing an investment agreement with a developed country or a developing country matters. It also examines the impact of regional investment agreements, namely between APEC and ASEAN countries on FDI inflows. Panel data estimations are undertaken and the results show that signing BITs attracts FDI inflows. However, it is BITs with developed countries that increase FDI inflows as compared to BITs with developing countries. Results indicate that investment agreement between APEC countries has increased FDI inflows but that amongst ASEAN countries has had no impact.
\end{abstract}

- JEL classifications: F21

- Key words: Determinants of Foreign Direct Investment, Bilateral Investment Treaties, Regional Investment Agreements, Economic Fundamentals

\section{Introduction}

The decade of 1990s has witnessed an extensive network of bilateral investment treaties (BITs) and regional investment agreements amongst Asian developing countries, which can be attributed to increased competition for foreign direct investment (FDI) inflows amongst the developing countries. These investment agreements seek to promote and protect FDI coming from the partner countries.

\footnotetext{
*Corresponding address: UNCTAD-India Programe, The Taj Ambassador Hotel, 2, Sujan Singh Park, Cornwall Road, New Dehli-110003, India, Tel: +91-11-2463-5036 (Ext. 13), Fax: +91-11-2463-5036, E-mail: rashmibanga@unctadindia.org,rashmibanga@yahoo.com (C2006-Center for International Economics, Sejong Institution, All Rights Reserved.
} 
The main provisions of these agreements whether bilateral or regional, is linked with gradual decrease or elimination of measures and restrictions on the entry and operations of foreign firms and application of positive standards of treatment with a view to eliminate discrimination against foreign enterprises. The investment agreements therefore seek to encourage FDI into the host countries. However, how far have these investment agreements helped in attracting FDI inflows is yet to be empirically estimated.

Until recently, there was a strong consensus in the literature that multinational corporations (MNCs) invest in specific locations mainly because of strong economic fundamentals in the host countries for example, large market size, stable macro economic environment etc. (Dunning 1993, Globerman and Shapiro 1999, Shapiro and Globerman 2001). However, with the growing integration of the world markets and increased competition amongst the host countries to attract FDI, it is argued that the host country's economic fundamentals may not be sufficient for inward FDI. Some of the studies have highlighted the role played by government policies in attracting FDI inflows [Brewer (1993), Grubert and Mutti (1991), Loree and Guisinger (1995), Taylor (2000), Kumar (2002), Contractor (1991), Caves (1996), Blomstrom and Kokko (2002) and Villela and Barreix (2002)]. But the results arrived at by these studies is mixed. A subset of these studies have also tested the impact of openness to trade and regional agreements in trade on FDI inflows and found them to be important determinants [e.g., Gastanaga, Nugent and Pashmova (1998), Taylor (2000), Chakrabarti (2001) and Asiedu (2002)].

The present study adds to the existing literature on determinants of FDI by empirically examining the impact of bilateral and regional investment agreements made by the host developing countries on FDI inflows, after controlling for the economic fundamentals of the host countries. It is the first attempt to test empirically the significance of bilateral investment treaties and regional investment agreements, namely between ASEAN and APEC countries, in attracting FDI flows to developing countries. It also investigates whether signing these agreements with developed and developing countries have differential impact on FDI inflows. The analysis is undertaken for fifteen developing countries ${ }^{1}$ of South, East and South East Asia for the period 1980-81 to 1999-2000 and panel data estimations have been carried out.

\footnotetext{
${ }^{1}$ Our sample includes Bangladesh, China, China- Hong Kong, India, Korea, Malaysia, Nepal, Pakistan, Philippines, Singapore, Sri Lanka, China-Taiwan, Indonesia, Thailand and Viet Nam.
} 
The rest of the study is organised as follows: Section 2 discusses BITs and regional investment agreements that have emerged since 1980s. Section 3 presents the theoretical framework and specifies the model to be estimated. Section 4 discusses the variables, data sources and expected relationships with the variables. Section 5 presents the results. Finally, Section 6 concludes the study.

${ }^{2}$ According to UNCTAD (1999) by the end of 1998 more than 1,700 BITs were concluded and nearly four fifths of them after 1990.

\section{Foreign Direct Investment Agreements}

\section{A. Bilateral Investment Treaties (BITs)}

In contrast to the number of multilateral trading agreements that have been made, very few investment agreements exist. However, there has been a substantial rise in number of bilateral investment treaties (BITs) that have been signed and brought into force in the last two decades and particularly in the $1990 \mathrm{~s}^{2}$ In general, BITs deal exclusively with investments and lay down specific standards of investment protection and transfer of funds. They contain provisions for the settlement of disputes both between the treaty partners and between investors and the host state. BITs also cover a number of other areas, in particular, non-discrimination in the treatment, and in some cases the entry of foreign-controlled enterprises, and other related fields. An important characteristic of BITs is a considerable uniformity in the broad principles underlying the agreements (UNCTAD 1999), coupled with numerous variations in the specific formulations employed. Important here is that BITs generally recognise the effect of national law on FDI and accept the right of governments to regulate entry of FDI. By providing protection, BITs are therefore expected to promote FDI.

BITs were initially addressed exclusively between developed and developing countries. A major reason for this being that developed countries were the major source of investments. However, the decade of 1990 has witnessed an increasing number of BITs between developing countries themselves. Table 1 shows the total number of BITs concluded in selected developing countries in different years ranging from 1980 to January 2000. We find that the total number of BITs has increased tremendously in the 1990s and countries like China, Indonesia, Malaysia,

${ }^{2}$ According to UNCTAD (1999) by the end of 1998 more than, 1,700 BITs were conclued and nearly four fifths of them after 1990. 
Table 1. Number of Bilateral Investment Treaties

\begin{tabular}{lccccc}
\hline \multicolumn{1}{c}{ country } & 1980 & 1985 & 1990 & 1995 & 2000 \\
\hline Bangladesh & 1 & 1 & 8 & 8 & 12 \\
China & 0 & 7 & 22 & 57 & 70 \\
Hong Kong, China & 0 & 0 & 0 & 6 & 14 \\
Taiwan, China & 0 & 0 & 1 & 9 & 11 \\
India & 0 & 0 & 0 & 1 & 13 \\
Indonesia & 7 & 7 & 8 & 19 & 30 \\
Korea, Rep. & 0 & 0 & 0 & 0 & 0 \\
Malaysia & 5 & 6 & 13 & 22 & 32 \\
Nepal & 0 & 1 & 2 & 3 & 3 \\
Pakistan & 2 & 4 & 7 & 10 & 15 \\
Philippines & 1 & 2 & 3 & 9 & 21 \\
Singapore & 6 & 6 & 9 & 13 & 19 \\
Sri Lanka & 4 & 13 & 16 & 17 & 20 \\
Thailand & 3 & 4 & 6 & 12 & 19 \\
Vietnam & 0 & 0 & 0 & 17 & 25 \\
Total & 29 & 51 & 95 & 203 & 304 \\
\hline
\end{tabular}

Source: UNCTAD 2001

Year of Entry into force of the Treaty has been considered.

Philippines and Vietnam have signed a large number of bilateral investment treaties in the period between 1995 to 2000. The number of BITs with developing countries has also increased overtime (Table 2) and has almost doubled in the period between 1995 to 2000. However, the number of BITs with developed countries has not increased at the same rate.

The objective of the study is to examine the impact of total number of BITs signed by a country in a particular year on FDI inflows. Further, to examine separately the impact of BITs with developed countries and developing countries on inward FDI.

\section{B. Regional Investment Agreements}

With regards to the regional investment agreements, we find that following the negotiations on TRIMS in the Uruguay Round of multilateral trade negotiations under the GATT (WTO), which reached an agreement on prohibiting trade related investment measures, some of the regional trade bodies have also taken the initiative to improve the investment environment to make it more conducive to free flow of FDI. One such agreement reached is among the APEC members, i.e., nonbinding investment principles (NBIP) in 1994. A similar agreement is also reached 
Table 2. Number of Bilateral Investment Treaties with Developed and Developing Countries

\begin{tabular}{lcccccccccc}
\hline & \multicolumn{1}{c}{1980} & \multicolumn{1}{c}{1985} & \multicolumn{2}{c}{1990} & \multicolumn{2}{c}{1995} & \multicolumn{2}{c}{2000} \\
\hline country & DC & DGC & DC & DGC & DC & DGC & DC & DGC & DC & DGC \\
Bangladesh & 1 & 0 & 1 & 0 & 6 & 2 & 6 & 2 & 7 & 5 \\
China & 0 & 0 & 6 & 1 & 15 & 7 & 35 & 22 & 38 & 32 \\
Hong Kong & 0 & 0 & 0 & 0 & 0 & 0 & 6 & 0 & 10 & 4 \\
India & 0 & 0 & 0 & 0 & 0 & 0 & 1 & 0 & 8 & 5 \\
Indonesia & 7 & 0 & 7 & 0 & 8 & 0 & 13 & 6 & 15 & 15 \\
Korea, Rep. & 0 & 0 & 0 & 0 & 0 & 0 & 0 & 0 & 0 & 0 \\
Malaysia & 5 & 0 & 5 & 1 & 10 & 3 & 12 & 10 & 13 & 19 \\
Nepal & 0 & 0 & 1 & 0 & 2 & 0 & 3 & 0 & 3 & 0 \\
Pakistan & 2 & 0 & 4 & 0 & 6 & 1 & 8 & 2 & 11 & 4 \\
Philippines & 1 & 0 & 2 & 0 & 3 & 0 & 5 & 4 & 13 & 8 \\
Singapore & 5 & 1 & 5 & 1 & 6 & 3 & 8 & 5 & 9 & 10 \\
Sri Lanka & 2 & 2 & 11 & 2 & 14 & 2 & 15 & 2 & 15 & 5 \\
Taiwan, China & 0 & 0 & 0 & 0 & 1 & 0 & 1 & 8 & 1 & 10 \\
Thailand & 3 & 0 & 4 & 0 & 4 & 2 & 6 & 6 & 8 & 11 \\
Vietnam & 0 & 0 & 0 & 0 & 0 & 0 & 10 & 7 & 13 & 12 \\
Total & 26 & 3 & 46 & 5 & 75 & 20 & 129 & 74 & 164 & 140 \\
\hline
\end{tabular}

Source: UNCTAD 2001, Based on Author's estimates

DC stands for Developed Country.

DGC stands for Developing country.

by Association of Southeast Asian Nations (ASEAN) in 1999. ASEAN Investment Area (AIA) has been signed by all the member countries under which member countries are committed to open up industries and grant national treatment to all ASEAN investors immediately, except in some industries of national interest. Impact of regional investment agreement on inward FDI is captured by a dummy variable that consists of membership of ASEAN and APEC.

\section{Theoretical Framework and Model Specification}

The emergence of FDI has been extensively explained by three corresponding streams of thoughts. First, the market imperfections hypothesis (Hymer 1976), which postulates that FDI is the direct result of an imperfect global market; second, the internalisation theory (Rugman 1986), where FDI takes place as multinationals replace external markets with more efficient internal ones; and third, the eclectic approach to international production (Dunning 1988) where FDI emerges due to ownership, internalisation and locatonal advantages. The development in different theories of FDI has been surveyed by Dunning (1999). 
What interest us are the determinants of cross-country pattern of FDI. In this regards, the determinants of inward FDI can be categorised into three groups. First, the economic fundamentals of the economy, e.g., market size, availability of skilled labour, etc. Second, selective government policies, i.e., those that aim at attracting FDI inflows and third international agreements, e.g., bilateral investment treaties and regional investment agreements. There is an extensive empirical literature on determinants of inward FDI that emphasises the economic conditions or fundamentals of the host countries relative to the home countries of FDI as determinants of FDI flows. This literature is in line with Dunning's eclectic paradigm (1993), which suggests that it is the locational advantages of the host countries that determines cross-country pattern of FDI.

The most important of these economic fundamentals, as recognised in the literature are the market-related variables. Here, there are two market familiar factors, i.e., current market size and potential market size. While a large market size generates scale economies, a growing market improves the prospects of market potential and thereby attracts FDI flows (Bhattacharya et al 1996, Chen and Khan 1997, Mbekeani 1997). Other economic fundamentals that are recognised with varying degrees of significance are availability of skilled manpower, cost of labour, cost of capital, availability of infrastructure and political and macroeconomic stability in the host countries (UNCTC 1992, Schneider and Frey 1985).

Apart from the market related factors studies have suggested selective government policies e.g., fiscal incentives and removal of entry restrictions as important determinant of FDI inflows. Brewer (1993) discuses various types of government policies that can directly and indirectly affect FDI through their effects on market imperfections. However, the empirical evidence on the impact of selective government policies on FDI inflows is mixed. Some of the studies find positive effect of investment incentives and negative impact of performance requirements e.g., Grubert and Mutti (1991), Loree and Guisinger (1995), Taylor (2000) and Kumar (2002).

However, there are studies e.g., Contractor (1991) that find policy changes to have a weak influence on FDI inflows. Caves (1996) and Villela and Barreix (2002) conclude that incentives are generally ineffective once the role of fundamental determinants of FDI is taken into account. This view is also supported by Hoekman and Saggi (2000) who conclude that although useful for attracting certain types of FDI, incentives do not seem to work when applied at an economy wide level. In a recent paper, Nunnenkamp (2002) argues that little has changed since 1980s and traditional market related determinants are still dominant factors attracting FDI. 
Another set of government policies that have been identified as an important determinant of FDI inflows in the 1990s is the openness to trade and regional agreements for trade. Globerman and Shapiro (1999) find that Canada-U.S. Free Trade Agreement (CUFTA) and North American Free Trade Agreement (NAFTA) increased both inward and outward FDI. Blomstrom and Kokko (1997) separate the effects of regional trade agreements (RTA) along two dimensions, i.e., the indirect effect on FDI through trade liberalisation and the direct effects from changes in investment rules connected with the regional trade agreements. According to them lowering interregional tariffs can lead to expanded markets and increase FDI but lowering external tariffs can reduce FDI to the region if the FDI is tariff jumping.

The impact of the third group of determinants, i.e., investment agreements on FDI inflows has not yet been tested empirically by the studies.

\section{A. Model Specification}

The focus of the study is on the impact of international investment agreements on FDI inflows after controlling for the economic fundamentals and selective government policies. The model formulated for this purpose is therefore as follows:

$F D I_{i t}=f\left[(\text { Economic Fundamental })_{i t-1},(\text { Tariff Policies })_{i t},(\text { FDI Incentives })_{i t}\right.$, (Removal of Restrictions on FDI) $)_{i t}$ (Bilateral Investment Agreements) $)_{\text {gct }}$, (Bilateral Investment Agreements) ${ }_{d c t}$, (Regional Investment Agreements) ${ }_{i t}$ ]

where $\mathrm{i}$ stands for country and $\mathrm{t}$ stands for the time period $=1980-81,1981$ 82.....1999-2000. dgc stands for developing countries and dc for developed

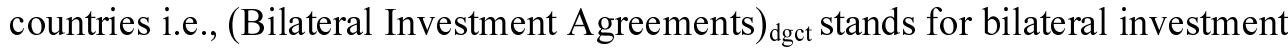
agreement with developing countries. Impact of economic fundamentals is estimated with a lag of one period to avoid simultaneity with the dependent variable. The impact of two regional investment agreements is examined, i.e., agreement reached among the APEC members, i.e., non-binding investment principles (NBIP) and investment area agreement (AIA) reached by Association of Southeast Asian Nations (ASEAN). The impact of these agreements is captured by the dummy variable for the country's membership of ASEAN and APEC. We now discuss in detail the methodology adopted and variables selected for the abovespecified model along with their data sources. 


\section{Variables, Data Sources and Expected Relationships}

To assess the impact of BITs and regional investment agreements on FDI inflows we control for the impact of two other groups of determinants, i.e., economic fundamentals and selective government policies.

\section{A. Economic Fundamentals as determinant of FDI}

Drawing on the vast existing literature on the impact of economic fundamentals on inflow of FDI we provide a list of variables used by the earlier studies and those that have been considered by us as determinants of inward FDI along with their expected signs (Table 3 ).

We control for the market variables (i.e., market size and potential market size), cost variables (i.e., cost of labour in terms wages and cost of capital), quality of human capital (i.e., education), macro-economic stability (i.e., exchange rate undervaluation and exchange rate stability), financial health (i.e., budget deficit and level of external debt) and infrastructure availability (i.e., transport and communication and electricity availability) in the economy. Studies have found market variables, quality of human capital, macro economic stability, financial health and infrastructure availability in the economy to have a positive impact while cost variables to have a negative impact on FDI inflows (UNCTC 1992). The definitions of the above variables and the data sources are reported in Table A.1 and Table A.2 respectively of the Appendix.

\section{B. Selective Government policies}

Government policies as a determinant of cross-country pattern of FDI flows have assumed greater importance in the current liberalised regime. However as observed by Globerman and Shapiro (1999) it is difficult to statistically examine FDI-specific policies since they are hard to isolate from other factors, "often because they are more implicit than explicit". Another of the difficulties in empirically examining the impact of these policies is the difficulty in quantifying these policies.

Studies that have empirically found a significant impact of government policies on FDI flows are generally based on benchmark surveys at a point of time (Kumar 2002, Loree and Guisinger 1995) or observe the impact of government policies on inward FDI for a particular country over a period of time. Though these kinds of studies give an insight into what determines the pattern of FDI flows at a particular 
Table 3. Economic Determinants

\begin{tabular}{|c|c|c|c|c|}
\hline Determinants & $\begin{array}{l}\text { Variables Used in he } \\
\text { Literature }\end{array}$ & $\begin{array}{l}\text { Empirical } \\
\text { Studies }\end{array}$ & $\begin{array}{l}\text { Variables Used in } \\
\text { this Study }\end{array}$ & $\begin{array}{l}\text { Expeced } \\
\text { Signs }\end{array}$ \\
\hline 1. Current Market & 1. Log GDP & Root and Ahmed & 1. Log GDP & \\
\hline Size and Potential & 2. Per Capita Income & 1979, Bhatta & 2. GDP Growth & \\
\hline Market Size & $\begin{array}{l}\text { 3. GDP Growth Rate } \\
\text { 4. Per Capita Growth } \\
\text { rate }\end{array}$ & $\begin{array}{l}\text { charya et al 1996, } \\
\text { Chen and Khan } \\
1997\end{array}$ & rate & + \\
\hline 2. Cost of Labour & 1. Real Wage Rate & $\begin{array}{l}\text { Woodward } \\
\text { and Rolfe } 1993\end{array}$ & Real wage rate & - \\
\hline 3. Availability of & 1. Literacy Rates & Schneider and & Secondary & \\
\hline Skilled Labour & $\begin{array}{l}\text { 2. Secondary } \\
\text { Enrolment rate }\end{array}$ & Frey 1985 & $\begin{array}{l}\text { Enrolment Rate, } \\
\text { Productivity } \\
\text { of Labour (GVA/ } \\
\text { Employee) }\end{array}$ & + \\
\hline 4. Cost of Capital & $\begin{array}{l}\text { 1. Local credit ratio } \\
\text { 2. Log annual average } \\
\text { lending rates }\end{array}$ & $\begin{array}{l}\text { Bende Nende, } \\
\text { et al } 2000\end{array}$ & $\begin{array}{l}\text { Log annual } \\
\text { average lending } \\
\text { rates }\end{array}$ & $?$ \\
\hline $\begin{array}{l}\text { 5. Availability of } \\
\text { Infrastructure }\end{array}$ & $\begin{array}{l}\text { 1. Ratio of Commerce, } \\
\text { transport and } \\
\text { communication to GDP } \\
\text { 2. Energy production } \\
\text { (equivalent tons of coal } \\
\text { per } 1000 \text { population) }\end{array}$ & $\begin{array}{l}\text { Bende-Nabende, } \\
\text { et al } 2000\end{array}$ & $\begin{array}{l}\text { 1.Proportion of } \\
\text { Electricity } \\
\text { Consumed / GDP } \\
\text { 2. Transport } \\
\text { and Communica- } \\
\text { tion/GDP }\end{array}$ & + \\
\hline $\begin{array}{l}\text { 6. Real exchange } \\
\text { rate }\end{array}$ & 1. Real exchange rate & $\begin{array}{l}\text { Goldberg and } \\
\text { Klein 1998, } \\
\text { Trevino, et al } 2002\end{array}$ & $\begin{array}{l}\text { Real exchange } \\
\text { Rate }\end{array}$ & - \\
\hline $\begin{array}{l}\text { 7. Exchange Rate } \\
\text { Stability }\end{array}$ & $\begin{array}{l}\text { 1. Percentage Change in } \\
\text { Annual Average } \\
\text { Exchange Rate between } \\
\text { Local Currency and US } \\
\$ \\
\text { 2. Exchange Rate } \\
\text { Volatility using Monthly } \\
\text { Data }\end{array}$ & $\begin{array}{l}\text { Froot and Stein } \\
1991\end{array}$ & $\begin{array}{l}\text { Percentage Change } \\
\text { in Annual } \\
\text { Average Exchange } \\
\text { Rate between } \\
\text { Local Currency } \\
\text { and US } \\
\$\end{array}$ & \\
\hline $\begin{array}{l}\text { 8. Rate of } \\
\text { Inflation }\end{array}$ & $\begin{array}{l}\text { Percentage Change in } \\
\text { Consumer prices }\end{array}$ & $\begin{array}{l}\text { Schneider and } \\
\text { Frey } 1985\end{array}$ & - & - \\
\hline $\begin{array}{l}\text { 9. Financial } \\
\text { Health }\end{array}$ & $\begin{array}{l}\text { 1. Current Account Deficit } \\
\text { 2. Ratio of External } \\
\text { Debts to Exports }\end{array}$ & $\begin{array}{l}\text { Schneider and } \\
\text { Frey } 1985\end{array}$ & $\begin{array}{l}\text { Ratio of External } \\
\text { Debts to Exports }\end{array}$ & - \\
\hline $\begin{array}{l}\text { 10. Overall } \\
\text { Economic } \\
\text { Stability that } \\
\text { includes Political } \\
\text { Stability }\end{array}$ & $\begin{array}{l}\text { 1. Credit Ratings } \\
\text { 2. Budget Deficit/ GDP }\end{array}$ & Trevino, et al 2002 & $\begin{array}{l}\text { Budget Deficit / } \\
\text { GDP }\end{array}$ & - \\
\hline
\end{tabular}


point in time, they do not capture the influence of change in the FDI policies in a particular country and its comparative attractiveness to inward FDI into that region overtime FDI may flow into a country not only because now the host country provides certain investment incentives but also because these incentives when compared to the incentives provided by other competing host countries appear to be more attractive. Also, an important fact that needs to be addressed is that though when considered individually different incentives offered by a host country may have significant influence on FDI, but when considered as a package, i.e., when all incentives offered by one host country are compared to those offered by other host country these incentives may lose their significance.

In an attempt to address the above issues and to quantify policies that are not captured by proxy variables and make them comparable across countries the methodology adopted is to allot scores to different countries for the policies offered by them overtime. These scores range from 0 to 2 , where a zero score is allotted to a country at a time when no incentives are offered by it. The score 1 or 2 is allotted for different incentive offered depending upon how conducive they are in attracting FDI.

Different scores with respect to different incentives have been allotted and their influence of FDI flows is empirically tested. But along with this the impact of composite score for incentives allotted to each country, i.e., a sum of all the scores allotted to it in a particular year for different incentives, is also examined. The influence of combined score on FDI flows allows us to see how important is the influence of the entire package of incentives offered by the host country. A similar exercise is undertaken with respect to removal of restrictions. The selective polices and their expected impact is now discussed:

\section{Investment Incentives}

There are two main categories of FDI incentives offered by developing countries. First is fiscal incentives, i.e., policies that are designed to reduce tax burden of a firm; and second is financial incentives, i.e., direct contributions to the firm from the government (including direct capital subsidies or subsidised loans). Fiscal incentives include tax concessions in the form of reduction of the standard corporate income-tax rate; tax holidays; accelerated depreciation allowances on capital taxes; exemption from import duties; and duty drawbacks on exports. Financial incentives include grants; subsidised loans and loan guarantees; publicly funded venture capital participating in investment involving high commercial risks; 
and government insurance at preferential rates.

These incentives are widespread as almost all countries in the sample have incentive schemes. Fiscal incentives are however preferred by the developing countries, partly because these can be easily granted without incurring any financial costs at the time of their provision ${ }^{3}$. The study therefore focuses on the fiscal incentives offered. The incentives covered by the study are the following:

a) Tax Holidays $\left(T A X H_{i t}\right)$ : A zero score is allotted to a country $\mathrm{i}$, in period $\mathrm{t}$, if no tax holidays are declared. If tax holidays are declared for five or more years a score of two is allotted and if it is less than five years a score of one is allotted.

b) Tax concessions in number of industries $\left(T A X C O N_{i t}\right)$ : A zero score is allotted to a country $i$, in period $t$, if tax incentives are declared for no industries. If tax incentives are declared for restricted number of industries then a score of one is allotted and if it is declared for all industries a score of two is allotted.

c) Repatriation of profits and dividends $\left(\right.$ REMITS $\left._{i t}\right)$ : A score of zero is allotted to a country for the period when approvals are required to repatriate remittances, one if some restrictions are imposed and two if no permission is required.

d) Corporate profit tax rates: This is captured by ratio of tax revenue from profits and capital gains to GDP.

The role of incentives in attracting FDI has been questioned on theoretical as well as empirical grounds as discussed earlier. The results with respect to impact of incentives offered by host countries to inward FDI are ambiguous in nature. Several studies with respect to incentives find that fiscal incentives do affect location decisions, especially for export oriented FDI, although incentives seem to play a secondary role (see Devereux and Griffith 1998, Guisinger and others 1985, Hines 1996). However, fiscal incentives appear unimportant for FDI that is geared primarily towards the domestic market; instead such FDI appear more sensitive to the extent to which it will benefit from import protection. However, as discussed earlier, incentives must be viewed as a package and this requires a more nuance view.

The impact of incentives on inward FDI flows is expected to be positive. But, it is interesting to see whether FDI from developing countries and from developed countries respond in a similar way to the incentives offered.

${ }^{3}$ Bora (2002) in a study of 71 developing countries concludes that fiscal incentives are the most popular, accounting for 19 out of 29 most frequently used incentives. 


\section{Removal of Restrictions}

Various forms of restrictions were applied to FDI in the developing countries in the pre-liberalised era. These relate to admission and establishment, ownership and control, and other operational measures. Admission and establishment restrictions included closing certain sectors, industries or activities to FDI; screening, authorisation and registration of investment and minimum capital requirements. Ownership and control restrictions existed in various forms. For example, allowing only a fixed percentage of foreign-owned capital in an enterprise; compulsory joint ventures; mandatory transfer of ownership to local private firms, usually over a period of time; and restrictions on reimbursement of capital upon liquidation. Even after entry foreign firms could face certain restrictions on their operations, such as restrictions on employment of foreign key personnel; and performance requirements such as sourcing or local content requirements, training requirements and export targets.

However, in the WTO regime, due to the enforcement of TRIMS (Trade Related Investment Measures) many of these restrictions have now been withdrawn and the types of restrictions relating to FDI have been greatly liberalised in a large number of countries in Asia. Many of them now do not require investment approvals or licensing except for few sectors that are closed to FDI (mainly for security reasons). The impact of the removal of the following restrictions is studied:

a) Access to industries $\left(A C C E S S_{i t}\right)$ : a score of zero is allotted to a country $\mathrm{i}$ in year $t$ if there exists restricted entry to foreign firms in a number of industries. The score of one or two is allotted depending upon whether the entry is restricted or free (excluding defence).

b) Foreign ownership restrictions $\left(O W N E R S H I P_{i t}\right)$ : a score of zero is allotted to a country $i$ in year $t$ if there exist high ceilings on foreign ownership. The score of one or two is allotted depending upon whether the ceiling is limited or no ceiling exists.

c) Ease of entry $\left(E N T R Y_{i t}\right)$ : a score of zero is allotted to a country $\mathrm{i}$ in year $\mathrm{t}$ if there exists restricted entry to foreign firms in terms of approvals or licensing required by them. The score of one or two is allotted depending upon whether the entry is made easier by reducing administrative procedures or by giving free access to foreign firms and no approvals are required.

d) Performance requirements (PERFOMANCE $\left.E_{i t}\right)$ : A score of zero is allotted if many performance requirements exist. A score of one is allotted if the number and degree of performance requirements are reduced and a score of two is allotted if no performance requirements exist. 
The impact of combined score for incentives, i.e., a sum of scores given for incentives and a combined score for removal of restrictions on inward FDI flows is examined. It is expected that a higher score will be associated with higher inflow of FDI. The analysis is also undertaken separately for FDI from developed and developing countries.

The policies with respect to incentives and restrictions on FDI for each country in the sample have been collected from Economic and Social Survey of Asia and the Pacific, United Nations (various issues), Asian Development Outlook and Country Economic Review, Asian Development Bank (various issues) and Country Reports on Economic Policy and Trade Practice, released by the Bureau of Economic and Business Affairs, U.S. Department of State.

\section{Tariff Policies}

In reviewing cross-country regressions on the determinants of FDI, Charkrabarti (2001) argues that after market size openness to trade has been the most reliable indicator of the attractiveness of a location for FDI. Studies like Globerman and Shapiro (1999) find that Canada-U.S. Free Trade Agreement (CUFTA) and North American Free Trade Agreement (NAFTA) increased both inward and outward FDI. Blomstrom and Kokko (1997) separate the effects of regional trade agreements (RTA) along two dimensions, i.e., the indirect effect on FDI through trade liberalisation and the direct effects from changes in investment rules connected with the regional trade agreements. According to them lowering interregional tariffs can lead to expanded markets and increase FDI but lowering external tariffs can reduce FDI to the region if the FDI is tariff jumping.

We therefore expect extent of openness of an economy to affect FDI inflows, particularly we expect lower tariff rates to attract higher FDI inflows. The impact of average tariff rates (TARIFF) on FDI inflows is examined. The sources of average tariff rates for the countries in the sample are UNCTAD's Trains database and WTO's Trade Policy Reviews and Integrated Data Base (IDB).

\section{Empirical Results}

The analysis is undertaken for fifteen developing countries of South, East and South East Asia for the period 1980-81 to 1999-2000 and an attempt is made to control for the economic fundamentals of the host country. To avoid the problem of simultaneity between the explanatory variables and the dependent variable (i.e., 
Log FDI), economic fundamentals are lagged by one year. Random effects as well as fixed effects models have been estimated but the analysis is based on random effects model since it is found to be more suitable by the Hausman Statistic ${ }^{4}$. Table 4 reports the results of the analysis.

The impact of economic fundamentals on FDI inflows are reported in column 1 of Table 4. Most of the variables reported have the expected signs and are consistent with the literature. FDI is found to be attracted to large market size; low labour cost; availability of high skill levels, captured by secondary enrolment ratio in the economy and high productivity of labour; lower external debt reflecting the financial health of the economy; and higher availability of electricity in the economy. However, cost of capital reflected by domestic lending rates, macro economic stability captured by exchange rate stability and budget deficit to GDP ratio are not found to be significant. Recent econometric studies emphasize that there has been a shift in the relative importance of the determinants of foreign investment decisions, i.e., away from fundamentals towards FDI policies that aim at attracting higher FDI flows in particular sectors. These studies suggest that effects of FDI incentives, in particular fiscal incentives, and other domestic FDI policies of the government have become more important ${ }^{5}$. One of the most discussed FDI policy of the host government has been with respect to the openness of the economy. We use the average tariff rates fixed by the host governments to determine the extent of openness of the economy.

Our results show that Tariff rates have a significant negative impact on FDI inflows (reported in column 2). This result is found to be robust in the sense that inclusion and exclusion of other variables do not affect its significance and sign. The result is as expected and corroborates the results of the earlier of studies e.g., Charkrabarti (2001) who finds that openness to trade attracts FDI after controlling for other factors. The result therefore suggests that in this period FDI that is attracted to developing Asian countries is not "tariff-jumping" in nature and countries with high average tariffs may be at a disadvantage as compared to countries with lower average tariffs in attracting FDI.

We study the impact of incentives offered as a package by the host countries and removal of restrictions on the operation of foreign firms separately. This is done on

${ }^{4}$ It should be noted that in most of the cases the results do not differ qualitatively between Fixed Effects model and Random Effects Model.

${ }^{5}$ UNCTAD 1996 
the presumption that these two may have separate effects on inward FDI. More than the fiscal incentives offered what may be of more importance to the foreign firms is the removal of restrictions on entry, ownership, access to industries, etc. Our results show that though incentives have a positive impact on inward FDI they are not significant determinants of FDI. Various studies show that incentives play a minor role in attracting $\mathrm{FDI}^{6}$ once the impact of economic fundamentals are controlled for. An argument put forward to explain this is that most countries eventually offer identical or similar incentives as competition for external resources intensifies. As a result, investors become less sensitive to these measures in their decisions to locate their investments.

However, the results show that removal of restrictions has a significant positive impact on FDI inflows into developing countries. This result is supported by the results arrived at by a growing body of literature that documents the difficulty that foreign firms face in establishing their operations in developing countries (e.g., Djankov and others 2002; Emery and others 2000). Djankov and others (2002) suggest that stricter regulation of entry is correlated with more corruption and a larger informal economy and therefore restrictions on entry may have a negative impact on FDI inflows. Also, it has been found that healthy economies have a high "churn rate" of firms, and research demonstrates a strong positive link between entry and exit (Love 1996) ${ }^{7}$. The results arrived at by Friedman and others (2000) also suggest that very often it is the arbitrary array of obstacles to starting and running business that are the more significant barriers to foreign investors.

Very recently, a new strand of literature has emerged that examines the impact of regional trading agreements on FDI flows (Binh and Haughton 2002, Worth 2002). Most of these studies argue that the determinants of FDI and trade are similar and therefore what determines trade also determines FDI. However, these studies have exclusively focussed on the impact of trade agreements on FDI. With regards to regional investment agreements, results show that the impact varies across different agreements. APEC membership has a significant impact on FDI inflows but ASEAN membership does not influence inflow of FDI. The results are however expected since ASEAN agreement, i.e., AIA is still new and may have an effect with a lag. There exist several multilateral agreements that include clauses on incentives and investment rules but their coverage remain limited. For instance,

\footnotetext{
${ }^{6}$ Caves (1996) and Villela and Barreix (2002)

${ }^{7}$ Entry barriers can also become exit barriers (World Bank 2003).
} 
WTO regulates FDI incentives in its agreements on Subsidies and Countervailing Measures (SCMs) and Trade-Related Investment Measures (TRIMS), but these agreements leave much discretion to national decision-makers, and apply only to 'specific subsidies' that are directed to individual enterprises ${ }^{8}$.

two equations are estimated, one using total number of BITs signed by the host country and second BITs signed with developing and developed source countries of FDI. An interesting result that emerges is that BITs has a significant positive impact on FDI inflows but it is BITs with developed countries that has a significant influence on FDI inflows. BITs with developing countries do not have a significant impact on FDI inflow. There are two possible explanations for this result. First, since FDI from developed countries comprises more than 60 percent of aggregate FDI therefore it is possible that BITs with developing countries may not show significance. Second, it is possible that determinants of FDI may differ between developed and developing countries and issues with respect to treatment of foreign firms in the host countries may not be important for FDI from developing countries.

Though as yet there does not exist any multilateral agreement on investment there has been an influx of bilateral agreements on investment that emphasize on the treatment of foreign firms by the host countries. To capture the impact of BITs on FDI inflows Summary and Conclusions

The study provides an empirical evidence on the impact of government policies and bilateral and regional investment agreements on FDI inflows into fifteen developing countries of South, East and South East Asia, for the period 1980-81 to 1999-2000, after controlling for the impact of economic fundamentals of the host country. Economic fundamentals, namely, large market size; low labour cost (in terms of real wages); availability of high skill levels (captured by secondary enrolment ratio and productivity of labour); lower external debt; and extent of electricity consumed in the economy are found to be significant determinants of aggregate FDI. After controlling for the effect of economic fundamentals, FDI policies are found to be important determinants of FDI inflows. Results show that lower tariff rates attract FDI inflows. However, fiscal incentives offered by the host governments are found to be less significant as compared to removal of restrictions in attracting FDI inflows.

${ }^{8} \mathrm{SCM}$ agreement prohibits subsidies that are contingent on export performance and use local inputs, and restricts the use of firm-specific subsidies exceeding 15 percent of total investment cost. 
Table 7. Impact of Selective Government Policies and Investment Agreements on Aggregate FDI: Dependent Variable: Log of Aggregate FDI Inflows

\begin{tabular}{|c|c|c|c|c|c|}
\hline Explanatory variables & 1 & 2 & 3 & 4 & 5 \\
\hline \multirow{2}{*}{ MKTSIZE } & $0.48^{* * *}$ & $0.37 * * *$ & $0.34 * *$ & $0.37 * *$ & $0.44 * *$ \\
\hline & $(2.78)$ & $(2.14)$ & $(2.02)$ & $(2.17)$ & $(2.62)$ \\
\hline \multirow{2}{*}{ GRTHMKT } & -0.002 & 0.004 & 0.001 & 0.005 & 0.003 \\
\hline & $(-0.45)$ & $(0.65)$ & $(0.17)$ & $(0.07)$ & $(0.49)$ \\
\hline \multirow{2}{*}{ COSTLB } & $-0.04 * * *$ & $-0.03 * * *$ & $-0.02 * *$ & $-0.02 * * *$ & $-0.03 * * *$ \\
\hline & $(-4.61)$ & $(-3.34)$ & $(-1.83)$ & $(-2.82)$ & $(-3.07)$ \\
\hline \multirow{2}{*}{ PDTYLB } & $0.03 * * *$ & $0.03 * * *$ & $0.02 * *$ & $0.02 * * *$ & $0.03 * * *$ \\
\hline & (4.69) & $(4.03)$ & $(2.09)$ & $(3.26)$ & $(3.54)$ \\
\hline \multirow{2}{*}{ EDU } & $0.07 * * *$ & $0.06 * * *$ & $0.04 * * *$ & $0.05 * * *$ & $0.06 * * *$ \\
\hline & $(7.97)$ & $(5.18)$ & $(3.51)$ & $(4.01)$ & $(4.39)$ \\
\hline \multirow{2}{*}{ EXRATE } & -0.004 & -0.006 & -0.001 & -0.007 & -0.003 \\
\hline & $(-0.03)$ & $(-0.43)$ & $(-0.86)$ & $(-0.53)$ & $(-0.27)$ \\
\hline \multirow{2}{*}{ EXTDEBT } & $-0.30 * * *$ & $-0.22 * * *$ & $-0.21 * *$ & $-0.20 * *$ & $-0.21 * *$ \\
\hline & $(-3.43)$ & $(-2.54)$ & $(-2.07)$ & $(-2.14)$ & $(-2.27)$ \\
\hline \multirow{2}{*}{$\mathrm{T} \& \mathrm{C}$} & -0.47 & -0.24 & 0.13 & 0.04 & 0.21 \\
\hline & $(-0.30)$ & $(-0.16)$ & $(0.09)$ & $(0.03)$ & $(0.15)$ \\
\hline \multirow{2}{*}{ ELECT } & $0.001 * * *$ & $0.001 * * *$ & $0.001 * * *$ & $0.001 * * *$ & $0.001 * * *$ \\
\hline & $(5.96)$ & $(6.06)$ & $(4.67)$ & $(4.68)$ & $(3.66)$ \\
\hline \multirow{2}{*}{ LDRATE } & 0.0001 & 0.0002 & 0.0009 & 0.0001 & 0.0002 \\
\hline & $(0.59)$ & $(0.90)$ & $(0.28)$ & $(0.57)$ & $(0.03)$ \\
\hline \multirow{2}{*}{ EXVOLATILITY } & -0.003 & -0.006 & -0.008 & -0.009 & -0.003 \\
\hline & $(-1.00)$ & $(-0.43)$ & $(-0.11)$ & $(-0.12)$ & $(-0.54)$ \\
\hline \multirow{2}{*}{ BUDGETDEF } & -0.002 & -0.005 & -0.003 & -0.005 & -0.009 \\
\hline & $(-0.35)$ & $(-0.78)$ & $(-0.66)$ & $(-0.05)$ & $(-0.39)$ \\
\hline \multirow{2}{*}{ TARIFF } & & $-0.03 * * *$ & $-0.01 * * *$ & $-0.02 * *$ & $-0.01 * *$ \\
\hline & & $(-3.03)$ & $(-3.51)$ & $(-2.16)$ & $(-2.48)$ \\
\hline \multirow{2}{*}{ REST } & & $0.13 * * *$ & $0.11 * * *$ & $0.10^{* * *}$ & $0.09 * * *$ \\
\hline & & $(4.00)$ & $(3.38)$ & $(3.17)$ & $(2.91)$ \\
\hline \multirow{2}{*}{ INCENTIVES } & & 0.25 & 0.43 & 0.40 & 0.45 \\
\hline & & $(0.16)$ & $(0.27)$ & $(0.28)$ & $(0.60)$ \\
\hline \multirow{2}{*}{ APEC } & & & $0.59 * *$ & & \multirow{4}{*}{ - } \\
\hline & & & $(2.39)$ & & \\
\hline \multirow{2}{*}{ ASEAN } & & & -0.83 & & \\
\hline & & & $(-0.66)$ & & \\
\hline BIT & & & \multicolumn{2}{|r|}{$\begin{array}{c}0.09^{* * *} \\
(2.76)\end{array}$} & \\
\hline BITDC & & & & - & $0.11 * * *$ \\
\hline \multirow{2}{*}{ BITDVGC } & & & & \multirow[b]{2}{*}{-} & $\begin{array}{l}(4.04) \\
0.006\end{array}$ \\
\hline & & & & & $(0.30)$ \\
\hline \multirow{2}{*}{ CONSTANT } & $1.91^{* *}$ & $2.81 * *$ & $3.59 * *$ & $2.84 * *$ & $3.43 * *$ \\
\hline & $(2.11)$ & $(2.15)$ & $(2.51)$ & $(2.08)$ & $(2.50)$ \\
\hline Adjusted R-squared (OLS) & 0.51 & 0.55 & 0.53 & 0.56 & 0.57 \\
\hline Observations & 270 & 255 & 255 & 255 & 255 \\
\hline Hausman & $33.59 *$ & 3.28 & 3.28 & 3.21 & 1.88 \\
\hline
\end{tabular}

Notes: 1.Results of Random Effects Model are presented. 2. Autocorrelation and Hetroscedasticity are corrected for 3.List wise deletion is made for missing values. 4.Hausman test supports random effect model. Figures in parenthesis are t-statistic. $* * *$ denotes significance at 1 per cent, $* *$ at 5 per cent and $*$ at 10 per cent. 
The results show that bilateral investment treaties (BITs) which emphasise on non-discriminatory treatment of FDI, play an important role in attracting FDI inflows into developing countries. However, bilateral investment agreements with developed countries and developing countries may have differential impact. Results show that BITs with developed countries have a stronger and more significant impact on FDI inflows as compared to BITs with developing countries. With respect to regional investment agreements we find that different regional investment agreements have different impact. While APEC is found to have a significant positive impact on FDI inflows ASEAN is not found to affect FDI inflow. However, it is noted that regional agreements may be still too new to show an impact in the period studied.

The above results of the study highlight the importance of government policies in attracting FDI inflows into developing countries. They show that apart from the economic fundamentals of the economy, which may attract FDI inflows, FDI policies of the host governments and investment agreements also play an important role. Within the selective FDI policies adopted by the government, it is the removal of restrictions on the operations of foreign firms in the host country that matter the most, especially to FDI coming from the developed countries. Bilateral investment agreements that focus on the non-discrimination in the treatment of foreign firms, lay specific standards of investment protection and contain provisions for the settlement of disputes, have an important impact on FDI inflows. BITs and regional investment agreements can therefore form an important policy instrument for attracting FDI inflows into developing countries.

Given the fact that FDI from developed and developing countries are attracted to different polices of the host governments, the question that arises is should the host governments in developing countries aim at attracting FDI from the developed countries and formulate their policies accordingly like signing investment agreements with developed countries or should they concentrate on policies like fiscal incentives to attract FDI from developing countries? The answer to this question is however beyond the scope of this study and is also country specific in nature since FDI from developed and developing countries constitute different shares in total FDI inflows in a particular country. But what comes out clearly from the analysis is that bilateral investment agreements with developed countries can boost FDI inflows into developing countries. 


\section{Acknowlegments}

I am extremely grateful to Dr. Arvind Virmani (ICRIER), Prof. K.L.Krishna (ICRIER) and Prof. B.N.Goldar (ICRIER) for their valuable insights and suggestions. The usual disclaimer nevertheless applies.

Received 15 November 2004, Accepted 5 May 2005

\section{References}

Agmon, T. (1979) "Direct investment and intra-industry trade: substitutes or complements?" in Giersch, H. (ed.) On the Economics of Intra-Industry Trade, JCB

Asiedu, E. (2002) On Determinants of Foreign Direct Investments to Developing Countries: Is Africa Different? World Development, 30 (11), 107-119.

Bhattacharya, A. Montiel, P.J. and Sharma, S., (1996) Private Capital Flows to Sub-Saharan Africa: An Overview of Trends and Determinants, Unpublished Paper, World Bank, Washington DC

Bende-Nabende, A. \& Ford, J.L. \& Sen, S. \& Slater, J. (2000), FDI locational determinants and the linkage between FDI and other macro-economic factors: Long-run dynamics in Pacific Asia, Discussion paper, 00-11, Department of Economics, University of Birmingham

Binh and Haughton 2002, Trade Liberalization and Foreign Direct Investment in Vietnam, Blomstrom, M and A. Kokko (1997) Regional Integration and Foreign Direct Investment A Conceptual Framework and Three Cases, policy research working paper 1750, The World Bank, International Economics Department, International Trade Division.

Blomström, M., A. Kokko and M. Zejan. (2000) Foreign Direct Investment: Firm and Host Country Strategies. London: Macmillan.

Blomström, M. and A. Kokko (2002). The Economics of Foreign Direct Investment Incentives, Working Paper 9489, NBER Working Paper Series.

Bora, B. (2002) Investment Distortions and the International Policy Architecture, World Trade Organisation, Working Paper, geneva.

Brewer T (1993) Government Policies, Market Imperfections and Foreign Direct investment, Journal of International Business Studies, 24,1 First Quarter, 101-121.

Caves, R. E. (1996) Multinational enterprise and Economic Analysis, Second EDITION, Cambridge: Cambridge University Press.

Chakrabarti, A. (2001) The Determinants of Foreign Direct Investment: Sensitivity Analyses of Cross-Country Regressions, Kyklos. 54(1): 89-113.

Chakrabarti Avik (2001) Determinants of FDI: A Comment on Globalization-Induced Changes and the Role of FDI Policies,

Chen, Zhaohui and Mohsin Khan (1997) Patterns of Capital Flows to Emerging Markets: 
A Theoretical Perspective, IMF Working Paper WP/97/13. International Monetary Fund, Washington DC.

Contractor, F (1991) Government policies towards Foreign Investment: An Empirical Investigation of the Link between National policies and Foreign Direct investment Flows, Paper Prepared for Annual Meeting of the Academy of International Business, Miami, Florida.

Devereux, M. and P. Griffith (1998), Taxes and Location of Production: Evidence from a Panel of U.S. Multinationals, Journal of Public Economics, 68 (3), 335-67.

Djankov, S., O. Hart and T. Nenova (2002) Efficiency Insolvency, Background

Papers for Doing Business in 2003, Report of Private Sector Advisory Services, World Bank, Washington, D.C.

Dunning, J.H. (1988) Explaining International Production, London: Unwin Hyman. , (1993) Multinational Enterprises and the Global Economy.

Wokingham, England: Addison-Wesley. , (1999), A Rose By Any Other Name ..? FDI Theory in Retrospect and Prospect, Mimeo, University of Reading and Rutgers University. , (2000) Editors, Reforms, Globalisation and Knowledge Based Economy,

Oxford, Oxford University press.

, (2002) Determinants of Foreign Direct Investment: Globalization Induced Changes and the Role of FDI Policies, in this issue.

Emery, J., M.T. Spence, L.T. Wells and T. Buehrer (2000), Administrative Barriersto

Foreign Investment: Reducing Red Tape in Africa, international Finance Corporation, Discussion Papers, Washington, D.C.

Ethier, W.J. (1994), "Multinational Firms in the Theory of International Trade", in Bacha, E. (ed.), Economics in a Changing World, Macmillan, London.

Ethier, W. J. (1996), "Theories about Trade Liberalisation and Migration: Substitutes or Complements" in Lloyd, P. J. and Williams, L. (eds), International Trade and Migration in the APEC Region, Oxford, Oxford University Press.

Eaton, Jonathan and Akiko Tamura, (1994) "Bilateralism and Regionalism in Japanese and US Trade and Foreign Direct Investment Relationships", Journal of Japanese and International Economics, 8, 478-510.

Friedman, E., S. Johnson, D. Kaufmann and P.Z. Lobaton (2000) Dodging the Grabbing Han: The Determinants of Unofficial Activity in 69 Countries, Lournal of Public Economics, 76(3), 457-93.

Froot, K.A. and J.C. Stein (1991), Exchange Rates and Foreign Direct investment: An Imperfect Capital Markets Approach, Quaterly Journal of Economics, 10(4), 1191-1217.

Gastanaga, V.M., J. b. Nugent, B. Pashmova (1998) Host Country Reforms and Foreign Direct investment Inflows: How much Difference do they Make?, World Development, 26(7): 1299-1314.

Globerman, S. and D. Shapiro (1999) The Impact of Government Policies on

Foreign Direct Investment: The Canadian Experience, Journal of International Business

Studies, Vol. 30 (3), 513-532. 
Goldberg, L., and Klein, M., (1998), Foreign Direct Investment, Trade and Real Exchange Rate Linkages in Developing Countries, in Glick, R. (ed.), Managing Capital Flows and Exchange Rates, Cambridge.

Grubert, Harry and John Mutti, (1991) Taxes, tariffs and Transfer Pricing in Multinational Corporate Decision Making, Review of Economics and Statistics, 5, 285-293.

Guisinger S.(1985), A Comparative Study of Country Policies. In S. Guisinger and Associates, investment Incentives and Performance Requirements, NY: Praeger.

Hines, J.R. (1996) Altered States: Taxes and the Location of Foreign Direct Investment in America, American Economic Review, Vol. 86, 1076-1094.

Hoekman B.and K. Saggi (2000) Assessing the Case for Extending WTO Disciplines on Investment Related Policies, World Bank Working Paper, Washington, D.C.

Hymer, S (1976) The International Operations of National Firms: A Study of Direct Investment, Ph. D. Thesis, MIT, 1960, Cambridge Mass, MIT Press.

Kokko (2002), Globalisation and Foreign direct investment Incentives, Paper Presented at Annual Bank Conference on development Economics in Europe, Oslo, Mimeo.

Kumar, N. (2001) WTO's Emerging Investment Regime and Developing Countries: The Way Forward for TRIMS Review and Doha Ministerial Meeting, Economic and Political Weekly, 36 (33), August 8, 315-58.

Kumar, N. (2002) Globalisation and the Quality of Foreign Direct Investment, Oxford University Press.

Loree. D. W. and Stephen E. Guisinger (1995), Policy and Non Policy Determinants of U.S. Equity Foreign Direct Investment, Journal of International Business Studies, Second Quarter.

Love J.H. (1996) Entry and Exit: A Country level Analysis, Applied Economics 28(4), 441-51.

Markusen (1995) The Boundaries of Multinational Enterprises and the Theory of International Trade, Journal of Economic Perspectives, 9,169-189.

Mbekeani K. K (1997), Foreign Direct Investment and Economic Growth, NIEPO Occasional Paper Series, September.

Mundell, R. (1957), International Trade and Factor Mobility," American Economic

Review 47: 321-35.

Nunnenkamp P. (2002) Determinants of Foreign Direct Investment Inflows: How Globalisation Changed the Rules of the Game? Kiel Institute for World economics, Working Paper No. 1122, Kiel.

Root, F. R. and A. A. Ahmed (1979), Empirical determinants of manufacturing direct investment in developing countries, Economic Development and Cultural Change, 27(4): 751-767.

Rugman, A.M. (1986) New Theories of the Multinational Enterprise: An Assessment of Internalisation Theory. Bulletin of Economic Research, 38 (2).

Schneider, F., and Frey, B., (1985) Economic and Political Determinants of Foreign Direct Investment, World Development, 13 (2).

Shapiro, D. and S. Globerman (2001) National Infrastructure and Foreign Direct Investment, 
Mimeo, Simon Fraser University (February).Taylor (2000)

Singh, H. and Jun, K.W., (1995), Some New Evidence on Determinants of Foreign Direct Investment in Developing Countries, World Bank Policy Research Working Paper No.1531, World Bank, Washington DC

Taylor, C.T. (2000) The Impact of Host Country Government Policy on US Multinational Investment Decisions, World Economy, Vol. 23, 635-648.

Trevino, L.J., J.D. Daniels and H. Arbelaez (2002), Market Reform and FDI in Latin America: An Empirical Investigation, Transnational Cor[porations, Vol. 11, No. 1,

UNCTC (1992) The Determinants of Foreign Direct Investment, A Survey of the Evidence, Division of Transnational Corporations and Investment, New York.

UNCTAD (1996) Incentives and Foreign Direct Investment. Current Studies, Series A, No. 30. New York and Geneva: United Nations.

UNCTAD (1999) Trends in International Investment Agreements: An Overview United Nations Publication, Sales No. E.99.11.D.23.

UN, The UN International Financial Statistics, Yearbook, New York, UN.

UN, UNESCO Statistical Yearbook, New York, Paris, UNESCO.

Villela L. and A. Barreix (2002) Taxation and Investment promotion, Background Note for Global Economic Prospects 2003, Washington: Inter American Development Bank.

Woodward D. and R.J. Rolfe (1993), The Location of Export Oriented Foreign direct investment in the Caribbean Basin, Journal of International Business Studies, 24(1): 12144.

World Bank (2003) Global Economic Prospects and Developing Countries: Global opportunities, Washington D.C.

World Investment Report (1998): Trends and Determinants. United Nations Conference on Trade and Development. New York and Geneva: United Nations.

Worth (2002) Regional Trade Agreements and Foreign Direct Investment Regional Trade Agreements and U.S. Agriculture/AER-771 U 77 


\section{Annex}

Table A.1. Variables and Definitions

\begin{tabular}{lll}
\hline \multicolumn{1}{c}{ Variables } & \multicolumn{2}{c}{ Abbreviation } \\
1. Log of FDI & MKTSIZE & Log of Foreign Direct Investment Inflows \\
2. Market Size & Log of real gross domestic product \\
3. Potential Market Size & GRTHMKT & Growth rate of real GDP \\
4. Efficiency Wage Rate & EFFWAGE & Labour Cost / Labour Productivity \\
5. Education & EDU & Log of secondary enrolment ratio \\
6. Real exchange Rate & EXRATE & Real effective exchange rates \\
7. Financial Health: & EXTDEBT & Ratio of external Debts toexports \\
8. Budget Deficit & BUDDEF & Budget Deficit / GDP \\
9. Transport and Commu & T\&C & Transport \& Communication/ GDP \\
10. Electricity Consumed & ELECT & Electricity Consumed/GDP \\
11. Lending Rate & LDRATE & Real domestic interest rates \\
12. Exchange rate Volatility & EXGVOL & Percentage Change in Annual exchange rate between \\
& & local currency and one US \$ \\
\hline
\end{tabular}

Table A.2. Variables and Data Sources of Economic Fundamentals

\begin{tabular}{ll}
\hline \multicolumn{2}{c}{ Variables } \\
\hline 1. FDI & World Investment Directory, United Nations, Vol VII, Part I\&II: Asia and the
\end{tabular}
Pacific and UNCTAD's Division on Investment, Technology and Enterprise Development compiles world wide statistics on foreign direct investment (FDI).

2. Market Size Key Indicators of developing Asian and Pacific Countries, ADB, Various issues

3. Potential Market Size Key Indicators of developing Asian and Pacific Countries, ADB, Various issues

4. Labour Costs: $\quad$ ILO, Geneva, Yearbook of Labour Statistics, various issues, UNIDO CD-ROM versions of UNIDO's Industrial Statistics Database at the 3 and 4 digit level of the ISIC classifications.and ASI, GOI for wages in India.

5. Labour Productivity UNIDO CD-ROM versions of UNIDO's Industrial Statistics Database at the 3 and 4 digit level of the ISIC classifications

6. Efficiency wage Computed

7. Education UNESCO

8. Real exchange rate International Financial Statistics, IMF, various issues

9. Financial Health: International Financial Statistics, IMF, various issues

10. MacroEconomic International Financial Statistics, IMF, various issues

Stability,

11. Transport and World Tables, World Bank and World Development Indicators, World Bank

Communication

12. Electricity Consumed Key Indicators of developing Asian and Pacific Countries, ADB, Various issues 13. Lending Rate Global Development Finance \& World Development Indicators.

14. Electricity Consumed Key Indicators of developing Asian and Pacific Countries, ADB, Various issues

Notes:1. Gross enrollment ratio, secondary level is the ratio of total enrollment, regardless of age, to the population of the age group that officially corresponds to the secondary level of education. Data for Taiwan for some of the variables has been collected from Taiwan Statistical Databook (CEPD) various issues. Data Source: United Nations Educational Scientific, and Cultural Organization (UNESCO) Institute for Statistics. 2002. World Education Indicators. Paris. 
Table A.3. Correlation Between Economic Fundamentals

\begin{tabular}{|c|c|c|c|c|c|c|c|c|}
\hline & LOGFDI & MKTSIZE & GDPGRTH & EFFWG & EDU & EXRATE & EXTDEBT & $\mathrm{TC}$ \\
\hline LOGFDI & 1.00 & 0.41 & 0.33 & 0.26 & 0.49 & 0.04 & -0.79 & -0.08 \\
\hline MKTSIZE & 0.41 & 1.00 & 0.21 & 0.23 & 0.01 & 0.14 & -0.07 & -0.37 \\
\hline GDPGRTH & 0.33 & 0.21 & 1.00 & 0.08 & -0.03 & 0.15 & -0.32 & -0.19 \\
\hline EFFWG & 0.26 & 0.23 & 0.08 & 1.00 & 0.08 & -0.13 & -0.13 & 0.02 \\
\hline EDU & 0.49 & 0.01 & -0.03 & 0.08 & 1.00 & 0.18 & -0.57 & 0.08 \\
\hline EXRATE & 0.04 & 0.14 & 0.15 & -0.13 & 0.18 & 1.00 & -0.01 & -0.13 \\
\hline EXTDEBT & -0.79 & -0.07 & -0.32 & -0.13 & -0.57 & -0.01 & 1.00 & 0.04 \\
\hline \multirow[t]{2}{*}{$\mathrm{TC}$} & -0.08 & 0.37 & -0.19 & 0.02 & 0.08 & -0.13 & 0.04 & 1.00 \\
\hline & LOGFDI & MKTSIZE & GDPGRTH & EFFWG & EDU & EXRATE & EXTDEBT & $\mathrm{TC}$ \\
\hline ELECT & 0.17 & 0.37 & 0.07 & 0.18 & 0.11 & -0.07 & -0.31 & 0.25 \\
\hline LDRATE & -0.08 & -0.02 & -0.12 & -0.21 & -0.27 & 0.16 & 0.18 & 0.16 \\
\hline BDGETDEF & -0.44 & 0.17 & 0.14 & -0.04 & 0.30 & 0.06 & -0.45 & -0.10 \\
\hline \multirow[t]{2}{*}{ EXGVOL } & 0.05 & 0.04 & 0.08 & -0.05 & -0.08 & -0.21 & -0.07 & -0.01 \\
\hline & ELECT & LDRATE & BDGETDEF & EXGVOL & & & & \\
\hline ELECT & 1.00 & -0.01 & 0.15 & 0.00 & & & & \\
\hline LDRATE & -0.01 & 1.00 & 0.14 & -0.14 & & & & \\
\hline BDGETDEF & 0.15 & 0.14 & 1.00 & 0.02 & & & & \\
\hline EXGVOL & 0.00 & -0.14 & 0.02 & 1.00 & & & & \\
\hline
\end{tabular}

